\begin{tabular}{|c|l|}
\hline Title & The A nodic Oxide Film on Iron in Neutral Solution \\
\hline Author(s) & Sato, N.; Kudo, K.; Noda, T. \\
\hline Citation & Memoirs of the Faculty of Engineering, Hokkaido University, 13(Suppl2), 15-27 \\
\hline Issue Date & 1973-03 \\
\hline Doc URL & http://hdl.handle.net/2115/37916 \\
\hline Type & bulletin (article) \\
\hline File Information & 13Suppl.2_15-28.pdf \\
\hline
\end{tabular}

Instructions for use 


\title{
THE ANODIC OXIDE FILM ON IRON IN NEUTRAL SOLUTION
}

\author{
N. SATo, K. Kudo and T. Noda \\ Electrochemistry Laboratory, Faculty of Engineering \\ Hokkaido University, Sapporo, Japan
}

\begin{abstract}
The composition of the anodic passive oxide film on iron in neutral solution has been investigated by cathodic reduction, chemical analysis and ellipsometry. The cathodic reduction using a borate solution of $\mathrm{pH} 6.35$ containing arsenic trioxide as inhibitor estimates iron in the film to be all iron (III), indicating that no magnetite layer is present. Oxygen in the film is estimated from the ellipsometric thickness to be in excess of the stoichiometric ferric oxide, suggesting the presence of bound water. The average composition is represented as $\mathrm{Fe}_{2} \mathrm{O}_{3} \cdot 0 \cdot 4 \mathrm{H}_{2} \mathrm{O}$, in which hydrogen may be replaced partly with iron-ion vacancy. The anodic oxide film is composed of an inner anhydrous ferric oxide layer, which thickens with the potential and an outer layer of hydrous ferric oxide whose thickness depends on the condition of passivation and environment.

The anodic oxide film formed in the oxygen-potential region has also been measured by cathodic reduction, and it is found that the film retains nearly constant thickness above a critical potential where transpassive dissolution begins to occur.
\end{abstract}

Résumé-La composition des films passifs d'oxyde anodique engendrés sur le fer dans une solution neutre a été étudiée par réduction cathodique, analyse chimique et éllipsométrie. La réduction cathodique avec une solution au borate de $\mathrm{pH} 6,35$ contenant du trioxyde d'arsenic comme inhibiteur, prouve que le fer présent dans le film est entièrement sous forme de fer (III), ce qui indique qu'il n'y a aucune couche de magnétite. A partir de l'épaisseur éllipsométrique, on estime que l'oxygène présent dans le film est en excès par rapport à l'oxyde ferrique stochiométrique, ce qui suggère la présence d'eau liée. La composition moyenne est représentée par la formule $\mathrm{Fe}_{2} \mathrm{O}_{3} .0,4 \mathrm{H}_{2} \mathrm{O}$, dans laquelle l'hydrogène peut être substitué partiellement par une lacune ion-fer. Le film d'oxyde anodique est composé d'une couche d'oxyde ferrique anhydre interne, qui épaissit avec le potentiel et d'une couche externe d'oxyde ferrique hydraté dont l'épaisseur dépend des conditions de passivation et de l'environnement.

Le film d'oxyde anodique formé dans la région du potentiel de l'oxygène a aussi été mesuré par réduction cathodique et on trouve que le film conserve une épaisseur presque constante au-dessus d'un potentiel critique où une dissolution transpassive commence à se manifester.

Zusammenfassung-Die Zusammensetzung anodischer, passiver Oxydfilme auf Eisen in neutralen Lösungen ist mittels kathodischer Reduktion, chemischer Analyse und Ellipsenmessung untersucht worden. Die kathodische Reduktior, welche eine borsaure Lösung von pH 6,35 mit einem Arsentrioxyd Gehalt als Inhibitor enthält, führt zu der Schätzung, dass das Eisen in dem Film völlig Eisen (III) ist und zeigt an, dass keine magnetische Schicht vorhanden ist. Sauerstoffgehalt wird in dem Film nach Ellipsenmessungsstärke höher als das stöchiometrische Eisenoxyd geschätzt und lässt auf Vorhandensein von gebundenem Wasser schliessen. Die durchschnittliche Zusammensetzung wird als $\mathrm{Fe}_{2} \mathrm{O}_{3} .0,4 \mathrm{H}_{2} \mathrm{O}$ gegeben, in welcher Wasserstoff teilweise mit Eisenionen Leerstellen ersetzt werden kann. Der anodische Oxydfilm setzt sich aus einer inneren, anhydrischen Eisenoxydschicht zusammen, welche mit der Spannung dicker wird, und einer Aussenschicht von wasserhaltigem Eisenoxyd, dessen Stärk von den Umständen der Passivierung und Umgebung abhängt.

Per anodische Oxydfilm, der in der Sauerstoff-Potential Region gebildet wurde, ist auch mit kathodischer Reduktion gemessen worden, und es wurde gefunden, dass der Film über ein kritisches Potential hinaus, wo transpassive Lösung beginnt, fast konstante Stärke beibehält.

\section{INTRODUCTION}

FOR THE composition of anodic passive oxide films on iron in aqueous solution a composite layer model comprising inner magnetite and outer ferric oxide has been suggested from thermodynamic considerations ${ }^{1}$ and cathodic reduction experiments ${ }^{2}$ of the film. In a previous paper, ${ }^{3}$ however, we demonstrated by means of cathodic reduction combined with ellipsometry that the anodic oxide film on iron in neutral

* Presented at the 3rd International Conference on Passivity of Metals, Cambridge, England, July 1970; manuscript received 5 July 1970. 
solution is a layer of partially hydrated iron (III) oxide rather than a composite layer of magnetite and ferric oxide.

This paper presents additional evidence that indicates more clearly all the iron to be ferric in the anodic oxide film, estimates the average composition of the film, and proposes a model that consists of an inner layer of anhydrous ferric oxide and an outer hydrous ferric oxide. Furthermore, the paper provides information on the anodic oxide film formed in the oxygen-potential region.

\section{EXPERIMENTAL TECHNIQUE}

The materials, apparatus and methods were essentially the same as those in previous papers. $^{3.4}$ The specimen was a polycrystalline iron of $99.9 \%$ purity in the form of sheet $50 \times 10 \times 1 \mathrm{~mm}$, annealed and electropolished before measurement. The solutions were mixtures of $0.15 \mathrm{~N}$ boric acid and $0.15 \mathrm{~N}$ sodium borate with or without sodium hydroxide, their $\mathrm{pH}$ being from $5 \cdot 45$ to 10.45 . They were de-aerated practically completely by purified nitrogen gas before transfer into the $60-\mathrm{ml}$ glass cell.

The specimen surface free from oxide films was made by cathodic reduction as reported previously, ${ }^{3}$ and the anodic oxide film was formed on it by potentiostatic oxidation for $1 \mathrm{~h}$. The film was then cathodically reduced and the solution was analysed for iron as a function of cathodic charge.

All the measurements were carried out at $25 \pm 1^{\circ} \mathrm{C}$. Potentials are referred to the saturated calomel electrode.

The notation used is as follows. $L$ is the film thickness measured by ellipsometry, $E$ the potential referred to sce, $i_{\mathrm{a}}$ and $i_{\mathrm{c}}$ the anodic and the cathodic cd, $Q_{\mathrm{a}}$ and $W_{\mathrm{Fe}}{ }^{\prime}$ the amount of charge passed and of iron dissolved during anodic oxidation, $Q_{\mathrm{f}}$ the charge of oxide film estimated as $Q_{\mathrm{f}}=Q_{\mathrm{a}}-Q_{\mathrm{Fe}_{\mathrm{e}}}$ where $Q_{\mathrm{Fe}_{\mathrm{e}}}$ is the charge equivalent to $W_{\mathrm{Fe}}{ }^{\prime}$ (valid except in the oxygen-potential region), $Q_{\mathrm{c}}$ and $Q_{\mathrm{Fe}}$ the amount of charge passed and of iron reductively dissolved from the film during cathodic reduction, $W_{\mathrm{Te}(\max )}$ the maximum amount of iron reductively dissolved from the film, $W_{\mathrm{Fe}}^{\mathrm{T}}$ the calculated amount of iron in the film from $Q_{\mathrm{f}}$ assuming iron (III), and $Q_{\mathrm{c}}{ }^{\circ}$ the cathodic charge required for the induction period of reductive dissolution of the film.

\section{RESULTS AND DISCUSSION}

\section{Cathodic reduction behaviour}

Effect of current density. The anodic oxide film was formed by 1-h potentiostatic oxidation at $+0.85 \mathrm{~V}$ in the solution of $\mathrm{pH} 8.42$ with the anodic charge $Q_{\mathrm{f}}=7.39$ $\mathrm{mC} / \mathrm{cm}^{2}$, equivalent to iron (III), $W_{\mathrm{Fe}}^{\mathrm{T}}=1.425 \mu \mathrm{g} / \mathrm{cm}^{2}$. It was then cathodically reduced at various constant cds in the same solution and the amount of iron $W_{\mathrm{Fe}}$ reductively dissolved from the film was measured as a function of cathodic charge $Q_{\mathrm{c}}$.

The results are shown in Fig. 1, where a potentiostatic reduction curve at $-0.90 \mathrm{~V}$ is also shown for comparison. The broken line indicates the calculated curve for reductive dissolution of ferric oxide at $100 \%$ current efficiency by the reaction $\mathrm{Fe}_{2} \mathrm{O}_{3}+6 \mathrm{H}^{+}+2 \mathrm{e} \rightarrow 2 \mathrm{Fe}^{2+}+3 \mathrm{H}_{2} \mathrm{O}$.

The current efficiency estimated from the linear part of the $W_{\mathrm{Fe}} / Q_{\mathrm{c}}$ curves at this $\mathrm{pH}$ is not $100 \%$ but about $80 \%$, independent of the cd. The maximum amount of iron dissolved from the film, $W_{\mathrm{Fe}(\max )}$, is seen however to depend on the cd. It increases with decreasing cd, but $W_{\mathrm{Fe}(\max )}=W_{\mathrm{Fe}}^{\mathrm{T}}$ is not attainable in this solution even at very small $\mathrm{cd}$. 


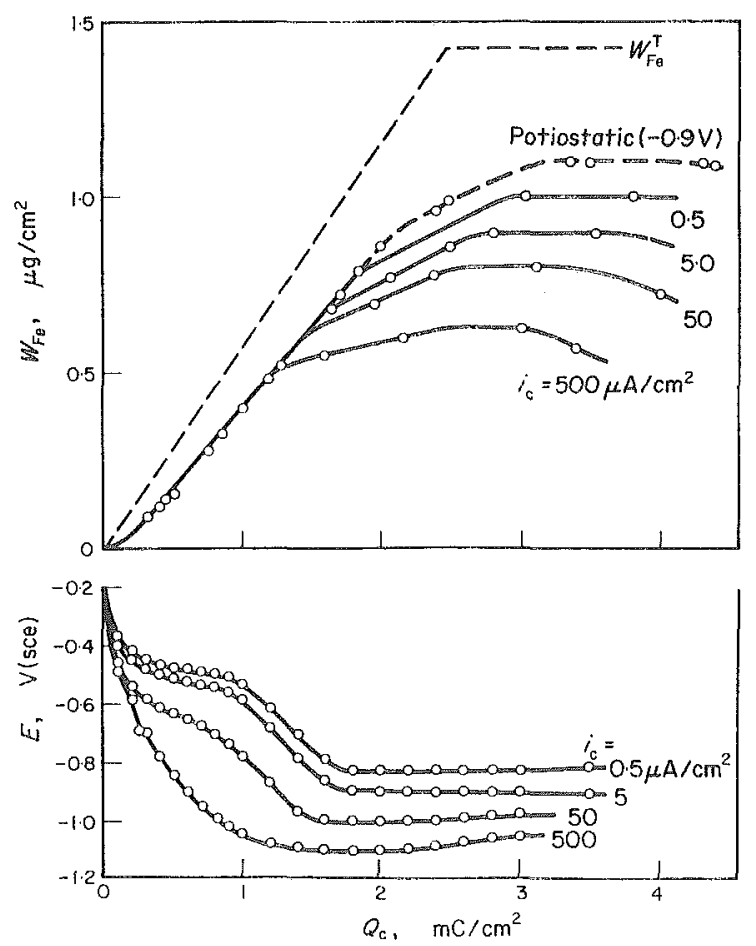

FIG. 1. Effect of current density on the cathodic reduction of anodic oxide film represented by potential $E$ and amount of iron $W_{\mathrm{Fe}}$ reductively dissolved from the film as a function of cathodic charge $Q_{c}, W_{\mathrm{Fe}(\max )}$ being the maximum amount of iron from the film and $W_{\mathrm{re}_{\mathrm{e}}}^{\mathrm{T}}$ the amount of iron calculated from anodic charge $Q_{q}$ of the film assuming iron (III).

The film was formed at $+0.85 \mathrm{~V}(\mathrm{sce})$ and reduced at various current densities in $0.15 \mathrm{~N}$ boric-borate solution of $\mathrm{pH} 8.42$.

Effect of $\mathrm{pH}$. The anodic oxide film, formed at $+0.655 \mathrm{~V}$ in the solution of $\mathrm{pH}$ 8.42 with $Q_{\mathrm{R}}=6.27 \mathrm{mC} / \mathrm{cm}^{2}$ and $W_{\mathrm{F}_{\mathrm{e}}}^{\mathrm{T}}=1.210 \mu \mathrm{g} / \mathrm{cm}^{2}$, was cathodically reduced at a constant cd of $5.6 \mu \mathrm{A} / \mathrm{cm}^{2}$ in the solutions of various $\mathrm{pH}$. Figure 2 gives the results. The current efficiency is seen to increase with decreasing $\mathrm{pH}$ towards its limit of $100 \%$, which is attained at $\mathrm{pH} 6 \cdot 35$. $W_{\mathrm{Fe}(\max )}$ also increases with decreasing $\mathrm{pH}$. Figure 3 shows the $\mathrm{pH}$ dependence of the ratio, $W_{\mathrm{Fe}(\max )} / W_{\mathrm{Fe}}^{\mathrm{T}}$, as well as the current efficiency, $\eta$, wherein the suggestion is made that $W_{\mathrm{Te}(\max )}$ would become equal to $W_{\mathrm{Te}}^{\mathrm{T}}$ at solution $\mathrm{pH}$ less than $6 \cdot 35$.

Experimentally, however, $W_{\mathrm{Ie}}$ continues to increase and exceeds $W_{\mathrm{Fe}}^{\mathbf{T}}$, though closer examination reveals that the rate, $\mathrm{d} W_{\mathrm{Fe}} / \mathrm{d} Q_{\mathrm{o}}$ differs before and after $W_{\mathrm{Fe}}$ exceeds $W_{\mathrm{Fe}}^{\mathrm{T}}$. This is probably due to the dissolution of underlying iron, which would occur at an appreciable rate in acid solution. To confirm the dissolution of iron from its bare surface, comparison was made of the rate of increase of dissolved iron in the final stage of cathodic reduction with the rate of dissolution of the iron having no surface oxide under the same condition of cathodic current and $\mathrm{pH}$. Figure 4 gives the result, which shows the same rate of iron dissolution for the two cases. Therefore, we attribute the excess amount of $W_{\mathrm{Fe}}$ over $W_{\mathrm{Fe}}^{\mathrm{T}}$ to the dissolution of metallic iron, which immediately follows the reductive dissolution of the film. 


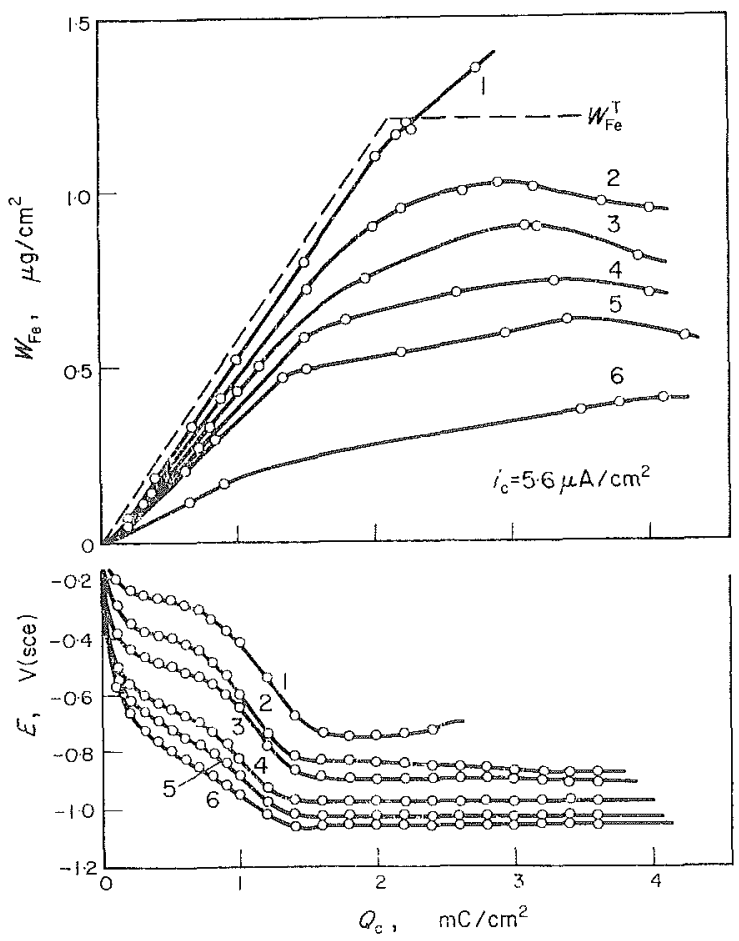

FIG. 2. Effect of solution $\mathrm{pH}$ on the cathodic reduction of anodic oxide film represented by $E / Q_{\mathrm{c}}$ and $W_{\mathrm{Fe}} / Q_{\mathrm{c}}$ curves. Curve 1 is for $\mathrm{pH}=6.35,2$ for $\mathrm{pH}=7.45,3$ for $\mathrm{pH}=8.42,4$ for $\mathrm{pH}=9.37,5$ for $\mathrm{pH}=10.05$ and 6 for $\mathrm{pH}=10.45$.

The film was formed at $+0655 \mathrm{~V}(\mathrm{sce})$ at $\mathrm{pH} 8.42$ and reduced at $5.6 \mu \mathrm{A} / \mathrm{cm}^{2}$ at various $\mathrm{pH}$ in $0.15 \mathrm{~N}$ boric-borate solution.

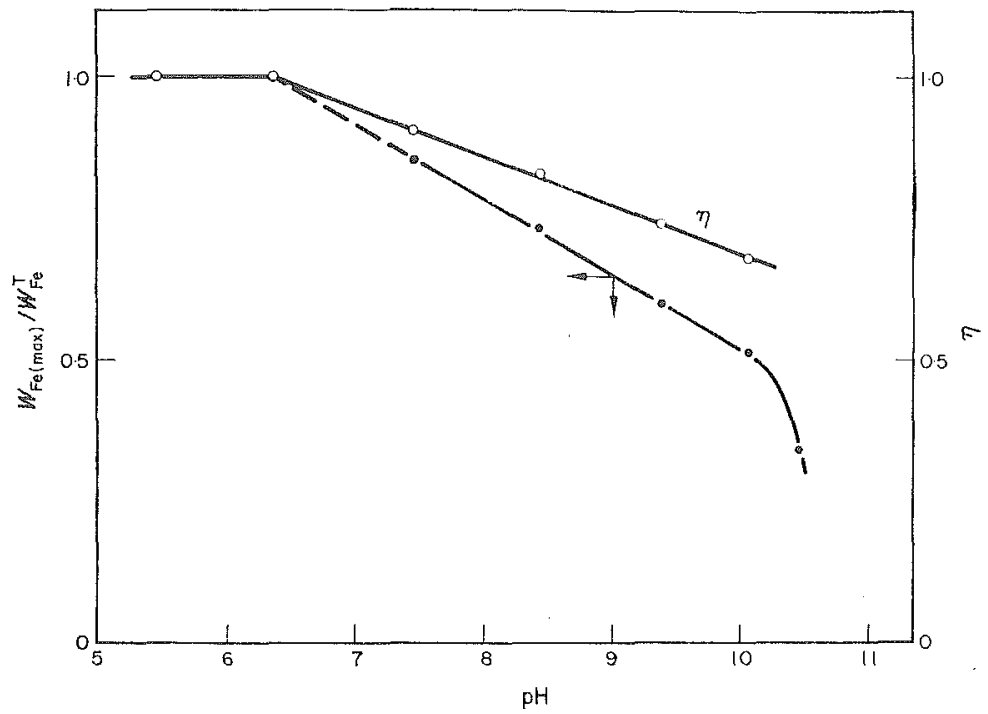

FIG. 3. Current efficiency $\eta$ and ratio $W_{\mathrm{Fc}(\max )} / W_{\mathrm{Fe}}{ }^{\mathrm{T}}$ in the cathodic reduction of anodic oxide film as a function of solution $\mathrm{pH}$ : data corresponding to those in Fig. 2. 


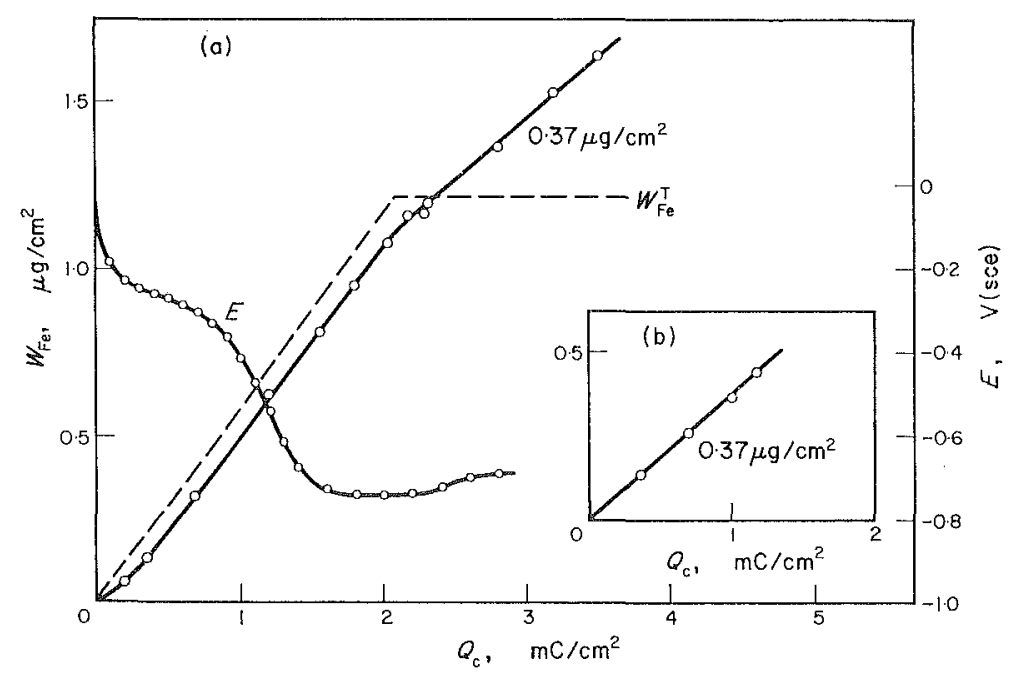

FIG. 4. Comparison in the rate of iron dissolution between the final stage of cathodic reduction of the film-covered iron and the cathodic polarization of the bare iron in $0 \cdot 15$ $\mathrm{N}$ boric-borate solution of $\mathrm{pH} 6.35$, showing them to be identical.

The film was formed at $+0.655 \mathrm{~V}(\mathrm{sce})$ at $\mathrm{pH} 8.42$ and reduced at $5.6 \mu \mathrm{A} / \mathrm{cm}^{2}$ at $\mathrm{pH} 6.35$; the bare iron was polarized cathodically at $5.6 \mu \mathrm{A} / \mathrm{cm}^{2}$ at $\mathrm{pH} 6.35$.

\section{Cathodic reduction for analysing the anodic oxide flim}

The results mentioned above have led us to assume that cathodic reduction in the solution of $\mathrm{pH} 6 \cdot 35$, if performed without any dissolution of iron substrate, would enable the total amount of iron in the film to be measured by analysing the solution

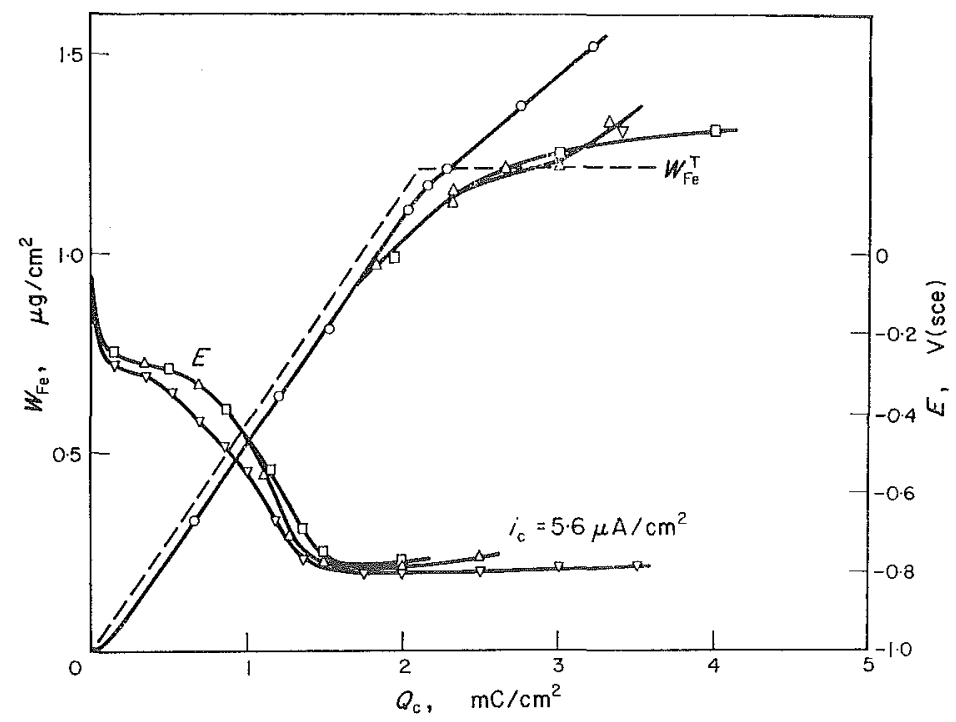

FIG. 5. Effect of various inhibitors on the cathodic reduction of anodic oxide film in

$0.15 \mathrm{~N}$ boric-borate solution at pH 6.35 . $O=$ without inhibitor. $\triangle=1.3 \times 10^{-2}$ $\mathrm{mol} / 1$ pyridine, $\nabla=3 \times 10^{-2} \mathrm{~mol} / \mathrm{H} \mathrm{HCHO}, \square=1 \times 10^{-4} \mathrm{~mol} / 1 \mathrm{NaCl}$.

The film was formed at $+0.655 \mathrm{~V}$ (sce) at $\mathrm{pH} 8.42$ and reduced at $5.6 \mu \mathrm{A} / \mathrm{cm}^{2}$ at $\mathrm{pH} 6.35$ with or without inhibitor. 
for dissolved iron ion, and it follows that if the total amount of iron $W_{\mathrm{Fe}(\max )}$ thus measured is equal to $W_{\mathrm{Fe}}^{\mathrm{T}}$ calculated from the anodic charge $Q_{\mathrm{f}}$ assuming iron (III), then all the iron in the film must be in the form of iron (III).

This was examined by using the solution of $\mathrm{pH} 6.35$ but containing various inhibitors. Figure 5 gives some results, in which pyridine, formaldehyde and sodium chloride are seen to inhibit, although not completely, the dissolution of the iron substrate. The best inhibitor we found is arsenic trioxide, dissolved as $\mathrm{HAsO}_{2}$ or $\mathrm{AsO}_{2}-$ in neutral solution. Figure 6 shows, for arsenic trioxide inhibition, the cathodic reduction curves of the films formed at $\mathrm{pH} 8.42$ and $\mathrm{pH} 10.30$ with the same $Q_{i}$ and hence the same $W_{\mathrm{Fe}}^{\mathrm{T}} . W_{\mathrm{Fe}}$ is seen to increase with $Q_{\mathrm{c}}$, initially very slowly, indicating

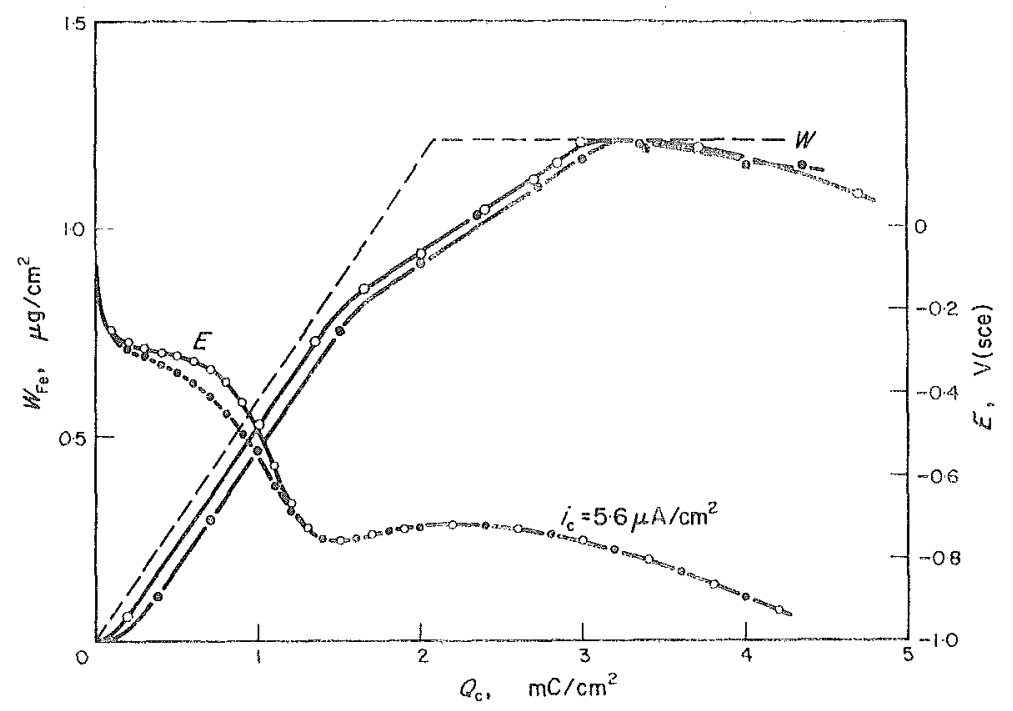

FIG. 6. Cathodic reduction of anodic oxide film in $0.15 \mathrm{~N}$ boric-borate solution of $\mathrm{pH}$ 6.35 containing $4 \times 10^{-4} \mathrm{~mol} / 1 \mathrm{As}_{2} \mathrm{O}_{3}$ as inhibitor, showing establishment of $W_{\mathrm{Fe}(\max )}=$ $W_{\mathrm{Te}}^{\mathrm{T}}$.

The films were formed at $+0.655 \mathrm{~V}$ (sce) at $\mathrm{pH} 8.42(\mathrm{O})$ and $10 \cdot 30$ (0), and reduced at $5.6 \mu \mathrm{A} / \mathrm{cm}^{2}$ at $\mathrm{pHI} 6.35$.

an induction period that depends on the $\mathrm{pH}$ of film formation, then at $100 \%$ current efficiency until a sudden drop in the rate occurs, and finally reaching $W_{\mathrm{Fe}}^{\mathrm{T}}$. The sudden drop in the current efficiency, which also corresponds to a break in the $E / Q_{\mathrm{c}}$ curve, is probably due to the cathodic reduction of $\mathrm{HAsO}_{2}$ or $\mathrm{AsO}_{2}^{-}$, which occurs on the bare part of the surface forming a protective film of arsenic on it, while the reductive dissolution of the film is still taking place on the oxide-covered part of the surface.

From the results shown in Fig. 6, it is made clear that all the iron ions in the film are in the state of iron (III) with a negligibly small amount of iron (II). Furthermore, the above results lead us to recommend the use of boric-acid-sodium-borate solution of $\mathrm{pH} 6.35$ with $\mathrm{As}_{2} \mathrm{O}_{3}$ of $4 \times 10^{-4} \mathrm{~mol} / \mathrm{l}$ for the estimation of iron in the anodic oxide film by means of cathodic reduction.

\section{Anodic oxide films in the oxygen potential region}

By making use of the solution recommended above we measured the anodic oxide film formed in the oxygen-potential region; the film in this region had not yet been 
made clear. The anodic oxide film was formed by 1 -h potentiostatic oxidation in the solutions of $\mathrm{pH} 7.45,8.42$ and 9.37 , and the solution was then analysed for iron to estimate the anodic dissolution in this potential region. After changing the solution to the solution of $\mathrm{pH} 6.35$ containing $\mathrm{As}_{2} \mathrm{O}_{3}$ the film was cathodically reduced and the amount of iron in the film was estimated.

Figure 7 gives the results. Immediately above the onset potential of oxygen evolution, the anodic oxide film appears to thicken. However, above a critical potential, where transpassive dissolution begins to occur, the anodic oxide film ceases to thicken and maintains a nearly constant thickness independent of the potential. The onset of transpassive dissolution of iron is at about $+1 \cdot 3 \mathrm{~V}$, which potential appears to be independent of the solution $\mathrm{pH}$.

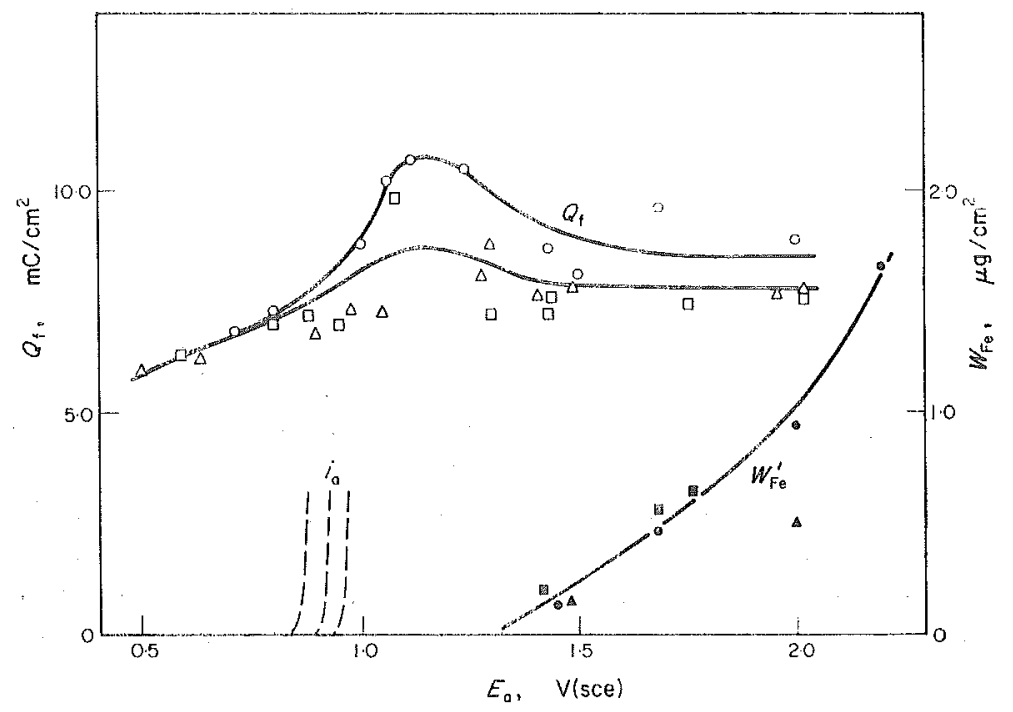

Fra. 7 . Anodic oxide film and transpassive dissolution of iron as a function of potential in the oxygen-evolution region, $Q_{1}$ being the anodic charge equivalent to iron in the film estimated by cathodic reduction and $W_{\mathrm{Fe}}$ the amount of iron dissolved during $1 . \mathrm{h}$ potentiostatic anodic oxidation. $\mathrm{O}=\mathrm{pH} 7.45, \Delta \Delta=\mathrm{pH} 8.42, \square$ 圈 $=\mathrm{pH} 9.37$.

We notice that in a potential region where the anodic oxide film loses its passivating property the film thickness does not increase with rise of the potential. This fact can be explained by a mechanical theory of film breakdown previously proposed by one of the authors (N. S) ${ }^{5}$, which has described thermodynamically the existence of a critical thickness above which the anodic oxide film breaks as a result of mechanical deformation due mainly to the high electrostriction pressure.

\section{Composition of anodic oxide films}

Figure 8 shows the film thickness $L$ measured by ellipsometry and the anodic charge $Q_{\mathrm{i}}$ by coulometry of the anodic oxide films formed by 1 -h potentiostatic oxidation at various potentials in the solutions of various $\mathrm{pH}$. Both $L$ and $Q_{\mathrm{f}}$ are seen to increase with the potential but appear not to depend on the solution $\mathrm{pH}$ at which the film is formed. 


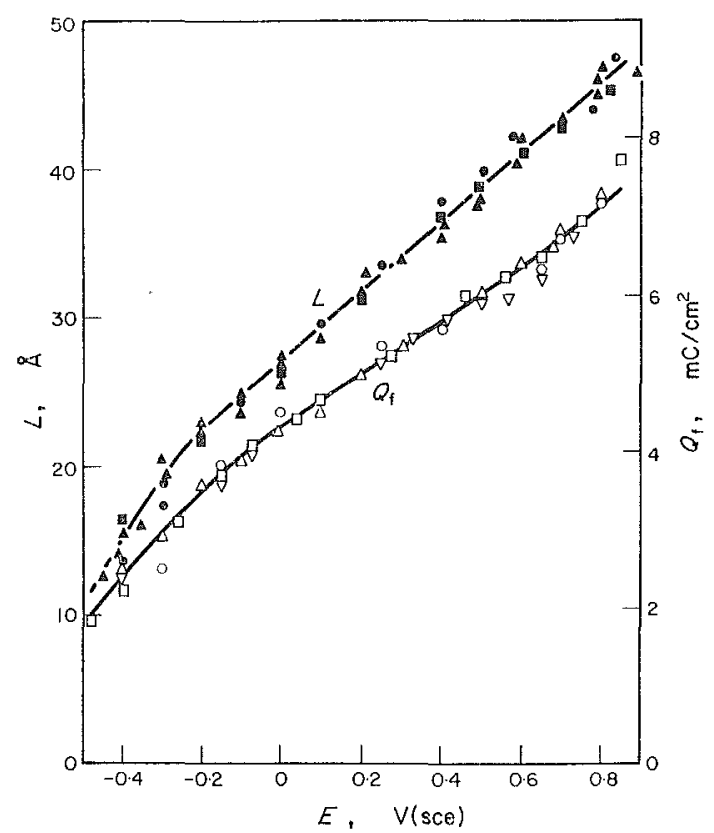

FIG. 8. Film thickness $L$ estimated by ellipsometry and anodic charge $Q_{\text {, estimated by }}$ coulometry as a function of potential in the passivity region.

Iron was potentiostatically oxidized for $1 \mathrm{~h}$ in $0.15 \mathrm{~N}$ boric-borate solutions of various $\mathrm{pH} . \mathrm{O}=\mathrm{pH} 7.45, \Delta \Delta=\mathrm{pH} 8.42, \square$ 圈 $=\mathrm{pH}$ 9.37, $\nabla=\mathrm{pH} 10.45$.

Since all the iron ions in the film are iron (III), as established above, the amount of iron in the film can be estimated from the anodic charge $Q_{\mathrm{f}}$. Furthermore, from the ellipsometric film thickness $L$ we can estimate the amount of oxygen in the film, assuming an fcc lattice of oxygen with lattice constant $4 \cdot 16 \AA,{ }^{6}$ which gives the number of oxygen atoms for unit thickness, $n_{0}=5.56 \times 10^{14}$ oxygen $/ \AA \cdot \mathrm{cm}^{2}$. Calculation was thus made based on the data shown in Fig. 8 assuming the surface roughness factor to be $1 \cdot 00$.

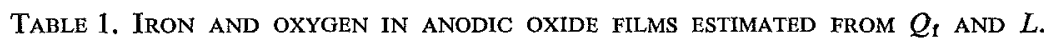

THE FILMS WERE FORMED AT CONSTANT POTENTIAL IN $0.15 \mathrm{~N}$ BORIC-BORATE SOLUTION OF PH FROM $7 \cdot 45$ TO $10 \cdot 45$. VALUES OF $Q_{\text {f }}$ AND $L$ ARE THE AVERAGES OF SEVERAL MEASUREMENTS. $N_{\text {T' }}$ AND $N_{O}$ ARE THE NUMBERS OF IRON AND OXYGEN ATOMS, AND $x$ THE EXCESS OF OXYGEN REPRESENTED AS $\mathrm{Fe}_{2} \mathrm{O}_{3+\infty}$ OR $\mathrm{Fe}_{2} \mathrm{O}_{3} \cdot x \mathrm{H}_{2} \mathrm{O}$

\begin{tabular}{ccccccc}
\hline $\begin{array}{c}E_{\mathrm{a}} \\
\mathrm{V}\end{array}$ & $\begin{array}{c}Q_{\mathrm{f}} \\
\mathrm{mC} / \mathrm{cm}^{2}\end{array}$ & $\begin{array}{c}N_{\mathrm{Fe}} \\
\mathrm{no} / \mathrm{cm}^{2}\end{array}$ & $\begin{array}{c}L \\
\AA\end{array}$ & $\begin{array}{c}N_{\mathrm{O}} \\
\mathrm{no} / \mathrm{cm}^{2}\end{array}$ & $N_{\mathrm{o}} / N_{\mathrm{Fe}}$ & $\begin{array}{c}X \\
\mathrm{Fe}_{2} \mathrm{O}_{3} . x \mathrm{H}_{2} \mathrm{O}\end{array}$ \\
\hline-0.2 & 3.50 & $0.73 \times 10^{16}$ & 22.5 & $1.25 \times 10^{16}$ & 1.71 & 0.43 \\
-0.1 & 3.95 & 0.82 & 25.0 & 1.39 & 1.70 & 0.39 \\
0 & 4.30 & 0.89 & 27.0 & 1.50 & 1.69 & 0.38 \\
0.1 & 4.68 & 0.98 & 29.5 & 1.64 & 1.68 & 0.36 \\
0.2 & 4.97 & 1.04 & 32.0 & 1.78 & 1.71 & 0.43 \\
0.3 & 5.35 & 1.11 & 34.0 & 1.89 & 1.70 & 0.39 \\
0.4 & 5.72 & 1.19 & 36.5 & 2.03 & 1.71 & 0.42 \\
0.5 & 6.04 & 1.25 & 39.0 & 2.17 & 1.74 & 0.46 \\
0.6 & 6.37 & 133 & 41.5 & 2.31 & 1.74 & 0.48 \\
0.7 & 6.75 & 1.40 & 43.7 & 2.43 & 1.74 & 0.47 \\
0.8 & 7.15 & 1.49 & 46.0 & 256 & 172 & 044 \\
\hline \multicolumn{7}{c}{ Mean } \\
\hline
\end{tabular}


Table 1 gives the results of calculation. It is evident that oxygen in the film is in excess of stoichiometric anhydrous ferric oxide. For the film to be stoichiometric and electrically neutral the excess oxygen has to be associated with proton to form partially hydrated ferric oxide, the average composition of which is given by $\mathrm{Fe}_{2} \mathrm{O}_{3} \cdot 0 \cdot 4 \mathrm{H}_{2} \mathrm{O}$ or $\mathrm{Fe}_{2} \mathrm{O}_{3} \cdot 1.4 \mathrm{FeOOH}$.

Hydrogen in the film has been measured to be represented as $\mathrm{Fe}_{2} \mathrm{O}_{3} \cdot 0 \cdot 2 \mathrm{H}_{2} \mathrm{O}$ by Yolken, Kruger and Calvert ${ }^{7}$ and as $\mathrm{Fe}_{2} \mathrm{O}_{3} \cdot 1 \cdot 99 \mathrm{H}_{2} \mathrm{O}$ by Kudo, Shibata, Okamoto and Sato. ${ }^{8}$

\section{Non-stoichiometric excess oxygen}

The anodic oxide films formed in the solutions of various $\mathrm{pH}$ but at the same potential of $+0.655 \mathrm{~V}$ with the same $Q_{\mathrm{f}}$ were cathodically reduced galvanostatically using the solution of $\mathrm{pH} 8.42$. Figure 9 gives the results, which reveals that the solution $\mathrm{pH}$ of film formation has no influence on the film except for the induction period appearing in the initial stage of the reductive dissolution of the film. Figure 10 shows more closely the induction period, wherein the charge $Q_{\mathrm{c}}{ }^{\circ}$ required for the induction period is estimated by extrapolation; $Q_{\mathrm{c}}{ }^{\circ}$ is not affected by the $\mathrm{cd}$ and $\mathrm{pH}$ of the cathodic reduction, as observed in Figs. 1 and 2. During the induction period both $L$ and $W_{\mathrm{Fe}}$ remain nearly constant at their initial values, suggesting that $Q_{\mathrm{c}}{ }^{\circ}$ is non-faradaic.

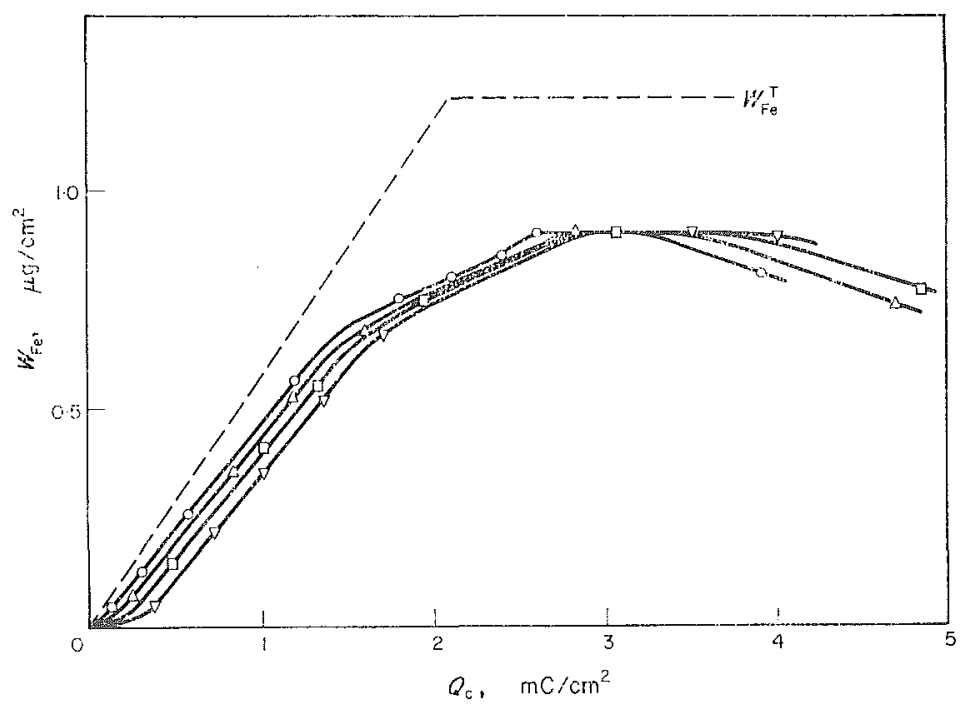

Frg. 9. Effect of solution $\mathrm{pH}$ of film formation on the anodic oxide film appearing in the initial stage of its cathodic reduction.

The films were formed at $+0.655 \mathrm{~V}$ (sce) at various $\mathrm{pH}(\mathrm{O}=\mathrm{pH} 7.45, \triangle=\mathrm{pH} 8.42$, $\square=9.37, \nabla=10.45$ ) and reduced at $5.6 \mu \mathrm{A} / \mathrm{cm}^{2}$ at $\mathrm{pH} 8.42 \mathrm{in} 0.15 \mathrm{~N}$ boric-borate solution.

Since $Q_{0}{ }^{\circ}$ is much larger than a simple electrical double-layer charge, we assume a capacitive charge due to sorption and desorption of proton, ${ }^{7}$ which may be written

$$
\mathrm{O}_{\mathrm{ex}}{ }^{2-}+2 \mathrm{H}^{+}\left(\text {sol) } \leftrightarrows \mathrm{H}_{2} \mathrm{O}\right. \text { (oxide) }
$$

where $\mathrm{O}_{\mathrm{ex}}{ }^{2-}$ is the excess oxygen ion not associated with proton. It follows then that the concentration of $\mathrm{O}_{\mathrm{ex}}{ }^{2-}$ increases with the $\mathrm{pH}$ as well as the potential. Figure 11 


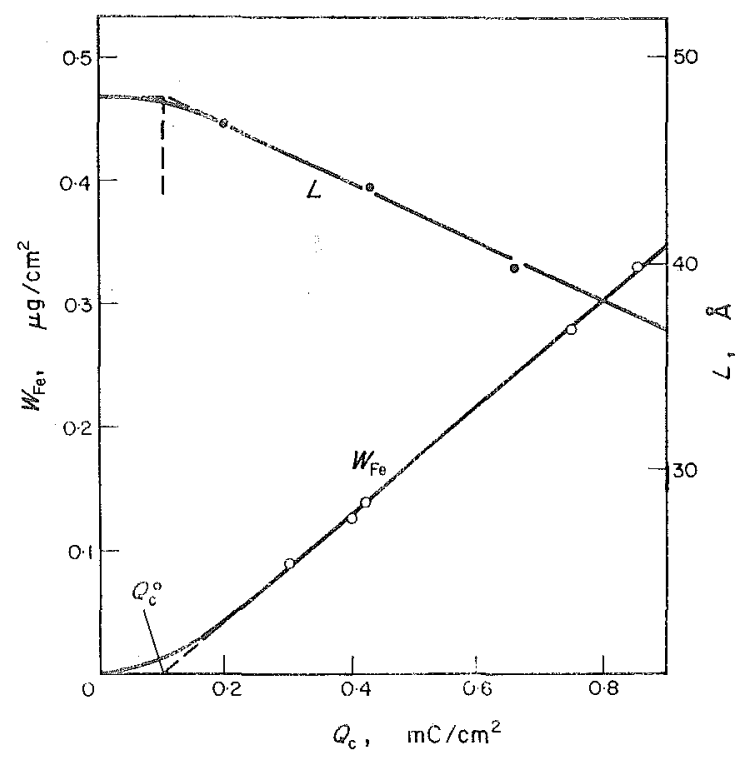

FIG. 10. Detail of the induction stage of cathodic reduction of anodic oxide film in terms of film thickness $L$ and amount of iron $W_{\text {Fe }}$ as a function of cathodic charge $Q$. The film was formed at $+0.85 \mathrm{~V}(\mathrm{sce})$ at $\mathrm{pH} 8.42$ and reduced at $5.6 \mu \mathrm{A} / \mathrm{cm}^{2}$ at $\mathrm{pH} 8.42 \mathrm{in}$ $0.15 \mathrm{~N}$ boric-borate solution

FIG. 11. Non-stoichiometric excess oxygen in anodic oxide film represented by ratio $Q_{\mathrm{c}}{ }^{\circ} / Q_{\mathrm{f}}$ as a function of potential and solution $\mathrm{pH}$ of film formation, $Q_{\mathrm{c}}{ }^{\circ}$ being the charge for the induction stage of cathodic reduction. $O$ present work; $\square$ from results by Nagayama and Cohen. ${ }^{2}$ The films were formed potentiostatically for $1 \mathrm{~h}$ in $0.15 \mathrm{~N}$ boric-borate solution, at several potentials at $\mathrm{pH} 8.42$ and at several $\mathrm{pH}$ values for potential $+0.655 \mathrm{~V}$ (sce).
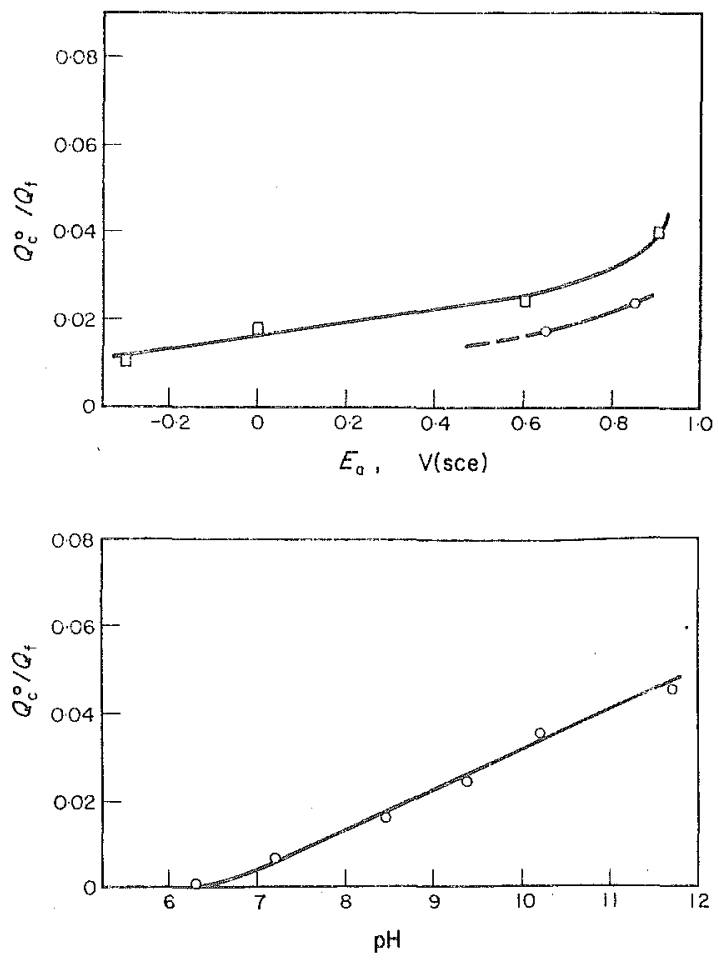
gives the ratio $Q_{\mathrm{e}}{ }^{\circ} / Q_{\mathrm{f}}$ as a function of $\mathrm{pH}$ and potential, which is in qualitative agreement with the assumption that $Q_{\mathrm{c}}{ }^{\circ}$ corresponds to $\mathrm{O}_{\mathrm{ex}}{ }^{2-}$.

The excess oxygen ion not associated with proton makes the film non-stoichiometric, and the extent of non-stoichiometry may be estimated from $Q_{0}{ }^{\circ}$; the ratio of $\mathrm{O}_{\mathrm{ex}}{ }^{2-}$ to $\mathrm{Fe}^{3+}$ in the film is $(3 / 2) \cdot\left(Q_{\mathrm{c}}{ }^{\circ} / Q_{\mathrm{f}}\right)$.

\section{Film thickness depending on the speed of passivation}

The thickness of anodic oxide films on iron depends not only on the potential of anodic oxidation but also on the speed at which the potential is set by potentiostat

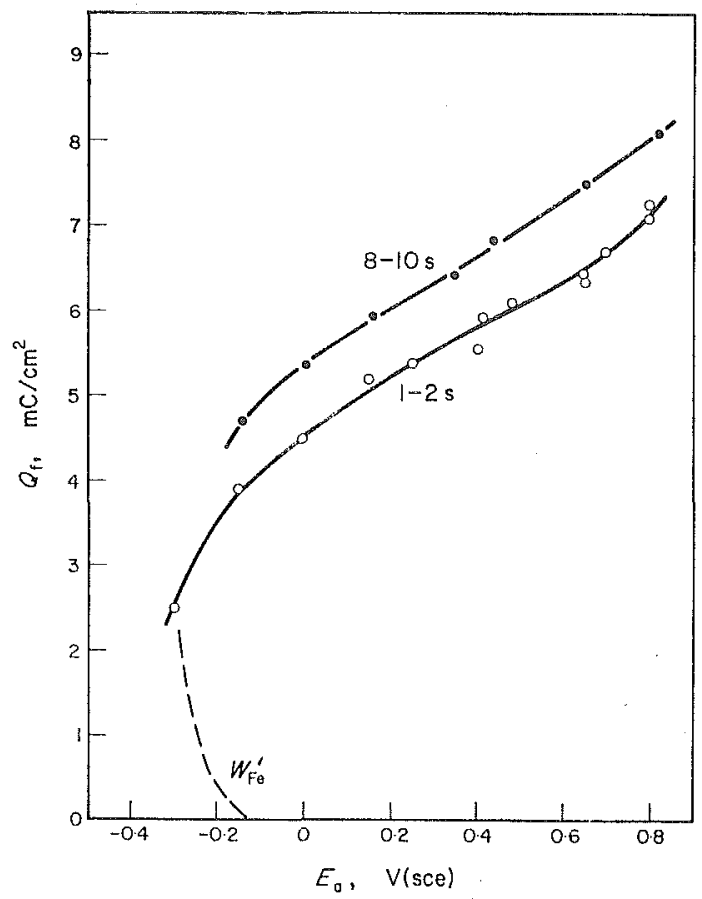

FIG. 12. Effect of the speed of passivation on the thickness of anodic oxide film represented by anodic charge $Q_{\mathrm{r}}$ as a function of potential.

The films were formed potentiostatically in $0.15 \mathrm{~N}$ boric-borate solution of $\mathrm{pH} 7.45$ with transition times of $1-2 \mathrm{~s}$ and $8-10 \mathrm{~s}$ for potential setting.

jumping over the active dissolution region. As shown in Fig. 12, the slower the speed of setting the potential, then the film becomes thicker even for the same duration of anodic oxidation. This is caused by anodic deposition of ferric oxide from ferrous ion dissolved from the metal in the active potential region, the amount of which increases with decreasing speed of passivation.

It is therefore reasonable to assume that the film consists of two layers, one whose thickness depends on the potential and the other whose thickness is determined by the anodic oxidation of ferrous ion in the solution ${ }^{10-12}$ rather than by the anodic oxidation of metallic iron.

\section{A MODEL OF THE ANODIC OXIDE FILM}

From the present results and the results in previous papers ${ }^{3.4}$ we can make a model of the anodic oxide film on iron, which is schematically represented in Fig. 13. The 

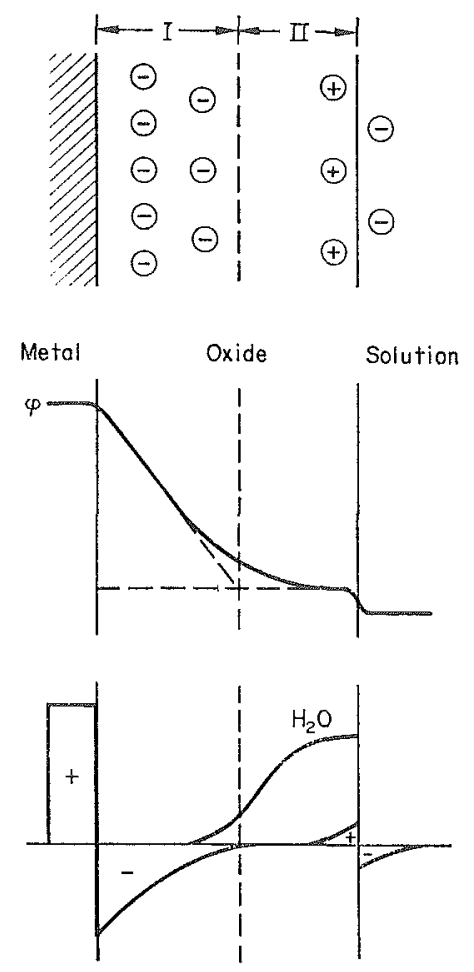

FIG. 13. Model of the anodic oxide film on iron and distribution of space charge, potential $\varphi$, and bound water. The inner layer is anhydrous ferric oxide with negative space charge and the outer layer is hydrous ferric oxide with bound water.

inner layer is anhydrous ferric oxide probably containing some amount of excess oxygen depending on the potential, and its thickness is determined by the potential. The outer layer is of hydrous ferric oxide containing bound water, the thickness of which is rather independent of the potential; this would grow to a considerable bulk in the presence of ferrous ion in the solution. The boundary between the layers, of course, will not be distinct, through the layers diffusing into each other.

The metal in contact with the semiconducting anhydrous or hydrous oxide, when polarized anodically, causes the accumulation of a negative charge in the space-charge layer in the oxide, the thickness of which, as represented by the Debye length, increases with decrease of the concentration of relatively free charge carriers, ie electrons and protons. Bound water in the oxide may serve as donor of electrons as well as protons. Protons will diffuse out of the space-charge layer leaving excess oxygen ions, which pull iron ions from the metal. At very high anodic field, most of the space charge will consist of excess oxygen ions because of depletion of free electrons. The potential profile across the film has been discussed in a previous paper, ${ }^{3}$ in which the inner layer is an electrically and ionically limiting barrier layer across which most of the anodic overvoltage develops.

\section{CONCLUSIONS}

A solution is recommended for the cathodic reduction to estimate the amount of iron in the film; this is a sodium-borate-boric-acid mixture of $\mathrm{pH} 6.35$ containing arsenic trioxide as inhibitor. 
Iron in the film is all ferric and oxygen is in excess of stoichiometric ferric oxide; hence hydrogen may be associated with excess oxygen to form bound water. The average composition is given by $\mathrm{Fe}_{2} \mathrm{O}_{3} .0 \cdot 4 \mathrm{H}_{2} \mathrm{O}$ or $\mathrm{Fe}_{2} \mathrm{O}_{3} .1 .4 \mathrm{FeOOH}$.

Any excess oxygen not associated with hydrogen makes the composition nonstoichiometric; this increases with potential and with solution $\mathrm{pH}$.

The film may be divided into two layers, an inner layer of anhydrous ferric oxide which thickens with increase of potential, and an outer layer of hydrous ferric oxide whose thickness depends on the solution environment. It is across the inner layer in which most of the overpotential develops.

The thickness of the film formed in the oxygen-evolution region ceases to increase and becomes potentiai-independent above a critical potential where the film loses its passivating property and transpassive dissolution of iron occurs.

\section{REFERENCES}

1. H. GöHR and E. LANGE, Naturwissenschaften 43, 12 (1956); Z. Elektrochem. Ber Bunsenges. phys. Chem. 61, 1292 (1957).

2. M. NaGayama and M. CoHEN, J. electrochem. Soc. 109, 781 (1962).

3. N. Sato, K. Kudo and T. NodA, Corros. Sci, 10, 785 (1970).

4. N. SATO and K. KUDO, Electrochim. Acta 16, 447 (1971).

5. N. Sato, Electrochim. Acta 16, 1683 (1971).

6. C. L. Foley, J. Kruger and C. N. J. Bechtoldt, J. electrochem. Soc. 114, 994 (1967).

7. H. T. Yolken, J. Kruger and J. P. Calvert, Corros. Sci. 8, 103 (1968).

8. K. Kudo, T. Shibata, G. Okamoto and N. Sato, Corros. Sci. 8, 809 (1963).

9. N. Sato, Electrochini. Acta 12, 1135 (1967).

10. M. Nagayama and M. Cohen, J. electrochem. Soc. 110, 670 (1963).

11. M. Nagayama and S. Kawamura, Electrochim. Acta 12, 1109 (1967)

12. V. Markovac and M. Cohen, J. electrochem. Soc. 114, 674 (1967). 